FOLIA POMERANAE UNIVERSITATIS TECHNOLOGIAE STETINENSIS

Folia Pomer. Univ. Technol. Stetin., Oeconomica 2018, 344(91)2, 93-100

Beata SADOWSKA

\title{
DYDAKTYKA ZADANIOWA A OCZEKIWANIA SŁUCHACZY STUDIÓW PODYPLOMOWYCH
}

\section{TEACHING TASKS AND EXPECTATIONS OF POSTGRADUATE STUDENTS}

Katedra Rachunkowości i Controllingu, Uniwersytet Szczeciński

ul. Cukrowa 8, 71-004 Szczecin, e-mail: beata.sadowska@wzieu.pl

\begin{abstract}
Summary. Education is currently characterized by the diversity of forms of education and accessibility at the level of studies, workshops and seminars. Knowledge, skills and competences can be gained and improved by adults inter alia at postgraduate studies. The aim of this study is to present an assessment of the postgraduate program "Budgetary accounting" and attempt to answer the question: What teaching standards and methodology do students expect at postgraduate studies? The research method was an anonymous questionnaire sent to students who were participants in postgraduate studies in the field of "Budgetary accounting", and developed questionnaires of the listeners were the research tool.
\end{abstract}

Słowa kluczowe: dydaktyka, studia podyplomowe, potrzeby słuchaczy.

Key words: didactics, post-graduate studies, the needs of students.

\section{WSTĘP}

Nauka i edukacja we współczesnym świecie stanowią ważny czynnik postępu społecznego i ekonomicznego, a kształcenie na studiach podyplomowych ma nie tylko dostarczać wiedzy, ale również nowych umiejętności, kompetencji zawodowych oraz praktycznych. Edukacja prowadzona na kierunku studiów podyplomowych rachunkowość budżetowa powinna w sposób profesjonalny przygotować kadrę dla komórek księgowości podmiotów sektora finansów publicznych, przy zastosowaniu najlepszych $z$ dostępnych metod i narzędzi prowadzenia procesu dydaktycznego.

Celem niniejszego opracowania jest zaprezentowanie oceny kierunku studiów podyplomowych rachunkowość budżetowa na podstawie opinii słuchaczy, którzy ukończyli II edycję tych studiów organizowanych przez Katedrę Rachunkowości i Controllingu Wydziału Zarządzania i Ekonomiki Usług Uniwersytetu Szczecińskiego. Kluczowe pytanie badawcze, na które starano się uzyskać odpowiedź zostało sformułowane następująco: Jakich standardów nauczania oraz metodyki prowadzenia zajęć oczekują słuchacze studiów podyplomowych?

Wyniki badania pozwalają na wstępne zidentyfikowanie kluczowych kwestii, problemów zgłoszonych przez słuchaczy oraz stanowią interesujący materiał do dalszych rozważań i ciągłego doskonalenia jakości prowadzonych studiów. 


\section{MATERIAŁ I METODY}

Badanie przeprowadzono wśród słuchaczy, którzy ukończyli studia podyplomowe na Wydziale Zarządzanie i Ekonomiki Usług Uniwersytetu Szczecińskiego oraz w Państwowej Wyższej Szkole Zawodowej w Koninie w czerwcu 2017 roku. Metodą badawczą była anonimowa ankieta przesłana słuchaczom studiów podyplomowych na kierunku rachunkowość budżetowa w roku akademickim 2016/2017. Do formułowania wniosków posłużyły również bezpośrednie wywiady kierownika studiów podyplomowych ze słuchaczami. Narzędziem badań były opracowane kwestionariusze słuchaczy. Badanie ankietowe składało się z 12 pytań zamkniętych. Pytania dotyczyły oceny studiów podyplomowych, w tym: programu studiów, treści merytorycznych przekazywanych przez wykładowców, jakości prowadzonych zajęć, przydatności poszczególnych przedmiotów, zastosowanych metod nauczania, komunikacji. Ankieta została rozesłana do 45 słuchaczy. W badaniu wzięło udział 17 słuchaczy.

W artykule wykorzystano następujące materiały: Uchwałę nr 155/2016 senatu Uniwersytetu Szczecińskiego z dnia 24 listopada 2016 r. w sprawie uchwalenia Regulaminu studiów podyplomowych Uniwersytetu Szczecińskiego, sylabusy opracowane w Katedrze na potrzeby realizacji programu kształcenia dla studiów podyplomowych „Rachunkowość budżetowa”.

\section{WYNIKI}

Badanie o charakterze pilotażowym miało na celu weryfikację stanu obecnego w aspekcie oceny efektywności i jakości prowadzonych studiów podyplomowych. Ocena studiów podyplomowych „Rachunkowość budżetowa” przez poszczególnych słuchaczy jest podobna. Większość z nich pozytywnie oceniła standardy i metody nauczania oraz komunikację wewnętrzną. Szczegółowe wyniki badania:

1. Wszyscy badani słuchacze wskazali, iż są zadowoleni z programu studiów podyplomowych „Rachunkowość budżetowa”.

2. Ocena poziomu zajęć na studiach podyplomowych kształtowała się następująco:

- 12 respondentów oceniło poziom zajęć jako dobry,

- 4 słuchaczy wskazało na ocenę bardzo dobrą,

- jedna osoba oceniła poziom zajęć, wskazując ocenę dostateczną.

3. Na pytanie: Czy przekazywane treści objęte programem studiów były aktualne i nowe? słuchacze biorący udział w badaniu odpowiedzieli w sposób następujący:

- wszystkie - $35 \%$ respondentów,

- zdecydowanie wszystkie - $18 \%$ respondentów,

- większość - $47 \%$ respondentów.

4. $35 \%$ respondentów uważa, iż zdecydowanie wszystkie przedmioty prezentowane w ramach studiów podyplomowych były przydatne, a 65\% badanych uznała, że większość przedmiotów była przydatna.

5. Piętnastu słuchaczy dobrze i bardzo dobrze oceniło przydatność materiałów dydaktycznych otrzymywanych w czasie studiów. Dwóch słuchaczy oceniło materiały dydaktyczne jako dostateczne, mierne. 
6. Na pytania: Jak Pani/Pan ocenia zastosowane metody nauczania? Czy dobór wykładów, ćwiczeń, warsztatów umożliwiał zdobycie i poszerzenia wiedzy? słuchacze biorący udział w badaniu odpowiedzieli:

- bardzo dobrze - $35 \%$ respondentów,

- dobrze $-47 \%$ respondentów,

- dostatecznie - $18 \%$ respondentów.

7. $82 \%$ słuchaczy biorących udział w badaniu potwierdziło bardzo dobry sposób komunikacji kierownika studiów ze słuchaczami.

8. Na pytanie: W jakim stopniu studia podyplomowe spełniły Pani/Pana oczekiwania? słuchacze biorący udział w badaniu odpowiedzieli:

- w bardzo wysokim - $12 \%$ respondentów,

- w wysokim - $76 \%$ respondentów,

- w dostatecznym $-12 \%$ respondentów.

9. Jeden uczestnik studiów podyplomowych „Rachunkowość budżetowa” stwierdził, że jego zdaniem studia podyplomowe nie są przydatną formą podnoszenia kwalifikacji zawodowych.

10. $70 \%$ respondentów wskazało, że ukończone studia podyplomowe pomogą im w rozwoju zawodowym lub zmianie pracy, $12 \%$ badanych słuchaczy jest odmiennego zdania, a $18 \%$ nie potrafi udzielić odpowiedzi.

11. Na pytanie: Kto Pani/Pana zdaniem powinien być wykładowcą na studiach podyplomowych? słuchacze odpowiadali następująco:

- wyłącznie pracownicy naukowo-dydaktyczni - brak odpowiedzi,

- głównie pracownicy naukowo-dydaktyczni - brak odpowiedzi,

- głównie wybitni praktycy - $37 \%$ respondentów,

- w równym stopniu pracownicy naukowo-dydaktyczni i praktycy $-63 \%$ respondentów.

12. Na pytanie: Jak Pani/Pan ocenia stronę organizacyjną studiów podyplomowych? respondenci odpowiadali następująco:

- powinno być więcej zajęć praktycznych;

- powinny być lepiej dostosowane godziny zjazdów do możliwości czasowych uczestników;

- liczba osób w grupie powinna być mniejsza;

- sale, w których odbywają się zajęcia, powinny być lepiej wyposażone;

- zasady zaliczania przedmiotów powinny być lepiej określone.

Bezpośrednie wywiady kierownika studiów podyplomowych ze słuchaczami, przeprowadzane w trakcie studiów, w czasie konsultacji oraz podczas sesji egzaminacyjnej i poprawkowej pozwoliły wyodrębnić obszary dysfunkcyjne wymagające poprawy.

Jednakże słuchacze wysoko ocenili:

- organizację zaliczeń oraz egzaminów, jak również brak pisemnej pracy końcowej. Podkreślali, iż jako osoby dorosłe, zatrudnione, dysponują ograniczonym czasem wolnym;

- rodzinną atmosferę od pierwszego zjazdu, integrację uczestników oraz wysoki poziom komunikacji;

- możliwość wymiany doświadczeń, wspólne rozwiązywanie problemów praktycznych, jakie występują w jednostkach organizacyjnych, w których są zatrudnieni, merytoryczną „burzę mózgów" opartą na doświadczeniach praktycznych;

- wykładowców praktyków oraz jakość prowadzonych przez nich zajęć. 


\section{DYSKUSJA I WNIOSKI}

Zgodzić się należy z Schultzem (1981), że czynnikiem decydującym o rozwoju gospodarczym jest działający człowiek. Może on rozwijać kapitał ludzki poprzez różne inwestycje, między innymi poprzez samokształcenie, zdobywanie doświadczeń zawodowych, dokształcanie i rozwijanie umiejętności. Służy temu między innymi dydaktyka.

Dydaktyka jako teoria nauczania i uczenia się służy pracy wykładowcy akademickiego oraz kierowanym przez niego studentom czy słuchaczom. Wykładowca najczęściej wykonuje zadania określające potrzeby nauczania, poradnictwa i instruktażu. Teoria kształcenia, jaką jest dydaktyka, jest podstawową nauką w służbie wykładowcy akademickiego i jego pracy. Dydaktyka zadaniowa dotyczy jednego kierunku studiów, obejmuje studia kierowane do jednolitej grupy studentów. Jako teoria kształcenia dydaktyka zadaniowa staje się ważną pomocą dla wykładowcy nie tylko w poznaniu i przyswajaniu określonych tematycznie wiadomości, twierdzeń czy teorii edukacyjnych; powinna służyć przede wszystkim wzbogacaniu praktyki nauczania oraz organizowania aktywności poznawczej słuchaczy studiów podyplomowych.

Ważną rolę w dydaktyce zadaniowej odgrywa wykładowca. Kompetencje i umiejętności dydaktyczne wykładowcy akademickiego wymagają przemyśleń oraz zastosowania ich w praktyce w postaci unowocześnienia i aktywizowania zajęć, wzbogacania stosowanych metod i środków dydaktycznych, optymalizowania form kontroli czy zasad oceny. Jest to trudne, gdyż słuchaczami są osoby dorosłe, najczęściej zatrudnione w sektorze przedsiębiorstw lub w sektorze finansów publicznych, posiadający określoną wiedzę, doświadczenie, mający sprecyzowane cele i oczekiwania dotyczące nauki zawodowej. Rolą dydaktyki zadaniowej jest zapewnianie odpowiedniego efektu kształcenia ${ }^{1}$, zadowolenie słuchaczy, przekazywanie praktycznej wiedzy zgodnie z programem kształcenia. Program kształcenia dla studiów podyplomowych „Rachunkowość budżetowa” obejmuje takie przedmioty, jak:

- wprowadzenie do rachunkowości;

- wprowadzenie do finansów publicznych;

- organizacja rachunkowości budżetowej;

- rachunkowość jednostek samorządu terytorialnego;

- rachunkowość samorządowych jednostek i zakładów budżetowych;

- kodeks postępowania administracyjnego i ordynacja podatkowa;

- zobowiązania podatkowe w sferze budżetowej;

- sprawozdawczość budżetowa i finansowa;

- podatek VAT w sektorze finansów publicznych;

- audyt wewnętrzny i kontrola zarządcza;

- rachunkowość zarządcza jednostek sektora finansów publicznych;

- partnerstwo publiczno-prywatne;

- zamówienia publiczne;

- budżet zadaniowy

- controlling środków unijnych.

\footnotetext{
${ }^{1}$ Należy w tym miejscu dodać, iż współcześnie społeczeństwo dorosłe jest coraz bardziej zainteresowane nauką i zdobywaniem wyższego wykształcenia oraz dokształcaniem zawodowym. Taki stan rzeczy determinuje korzyści nie tylko dla jednostki, ale również przekłada się bezpośrednio na inne pozytywne efekty (rozwój demokracji, wzrost wykształcenia dzieci, większą aktywność społeczną obywateli i tp.). Więcej zob. Stocker i in. (1998); Wolter (2001).
} 
Obejmują one 192 godziny zajęć dydaktycznych, na które składają się wykłady, ćwiczenia, zajęcia warsztatowe, case study. Dydaktycznymi celami studiów podyplomowych „Rachunkowość budżetowa" są:

- zdobycie przez słuchaczy wiedzy na temat funkcjonowania podsystemu rachunkowości budżetowej;

- wykształcenie i utrwalenie umiejętności kojarzenia zasad ewidencji księgowej na podstawie klasyfikacji budżetowej oraz planowania operacyjnego i strategicznego;

- wymiana wiedzy oraz doświadczenia na gruncie praktyki gospodarczej („burza mózgów”, doświadczenia zawodowe innych słuchaczy, wymiana doświadczeń, rozwiązywanie problemów, konfrontacja różnych zagadnień praktycznych występujących w jednostkach budżetowych).

Dydaktyka zadaniowa w zakresie studiów podyplomowych „Rachunkowość budżetowa” ma za zadanie uzyskanie przez słuchaczy określonych efektów kształcenia, co przedstawiono $w$ tab. 1.

Tabela 1. Opis efektów kształcenia na studiach podyplomowych „Rachunkowość budżetowa”

\begin{tabular}{|c|c|}
\hline Obszar & Efekty kształcenia \\
\hline \multirow{4}{*}{ Wiedza } & $\begin{array}{l}\text { Słuchacz wskazuje zakres podmiotowy i przedmiotowy kluczowych aktów prawnych doty- } \\
\text { czących funkcjonowania jednostek sektora finansów publicznych oraz rozumie zasady ich } \\
\text { funkcjonowania w gospodarce rynkowej }\end{array}$ \\
\hline & $\begin{array}{l}\text { Słuchacz charakteryzuje system rachunkowości budżetowej, posługuje się fachową ter- } \\
\text { minologią związaną z wyceną aktywów i pasywów, dochodami i wydatkami, rozumie zasady } \\
\text { (politykę) rachunkowości i opisuje elementy sprawozdania finansowego }\end{array}$ \\
\hline & Słuchacz charakteryzuje zadania realizowane przez jednostki sektora finansów publicznych \\
\hline & $\begin{array}{l}\text { Słuchacz rozróżnia i charakteryzuje podatki, opłaty i inne obciążenia wynikające z działalności } \\
\text { jednostek sektora finansów publicznych }\end{array}$ \\
\hline \multirow{4}{*}{ Umiejętności } & $\begin{array}{l}\text { Słuchacz potrafi wyceniać składniki bilansowe i wynikowe, ewidencjonuje operacje gospo- } \\
\text { darcze i sporządza sprawozdanie finansowe w ramach systemu rachunkowości budżetowej } \\
\text { i finansowej }\end{array}$ \\
\hline & $\begin{array}{l}\text { Słuchacz podejmuje decyzje na podstawie informacji pochodzących z systemu rachunkowości } \\
\text { budżetowej i inne decyzje organizacyjne w ramach realizacji zadań jednostek sektora finansów } \\
\text { publicznych }\end{array}$ \\
\hline & $\begin{array}{l}\text { Słuchacz zarządza informacjami finansowymi i niefinansowymi w ramach sektora finansów } \\
\text { publicznych }\end{array}$ \\
\hline & $\begin{array}{l}\text { Słuchacz interpretuje przepisy prawa i na ich podstawie rozwiązuje problemy praktyki } \\
\text { gospodarczej }\end{array}$ \\
\hline \multirow{2}{*}{$\begin{array}{l}\text { Kompetencje } \\
\text { społeczne }\end{array}$} & $\begin{array}{l}\text { Słuchacz wykazuje odpowiedzialność za informacje pochodzące z systemu rachunkowości } \\
\text { budżetowej. Potrafi samodzielnie planować }\end{array}$ \\
\hline & $\begin{array}{l}\text { Słuchacz wykazuje kreatywność w wyciąganiu wniosków na podstawie informacji pocho- } \\
\text { dzących z systemu rachunkowości budżetowej }\end{array}$ \\
\hline
\end{tabular}

Źródło: opracowano na podstawie Autorskiego programu kształcenia dla studiów podyplomowych „Rachunkowość budżetowa" obowiązującego w roku akademickim 2017/2018.

Metodami weryfikacji efektów kształcenia są zaliczenie, egzamin ustny, prezentacja, projekt oraz zajęcia praktyczne (weryfikacja poprzez obserwację).

Studia podyplomowe na Uniwersytecie Szczecińskim są prowadzone na podstawie Regulaminu studiów (Uchwała nr 155/2016 Senatu Uniwersytetu Szczecińskiego), który wskazuje, iż są one prowadzone w formie studiów niestacjonarnych przez dwa semestry, w języku polskim. Prowadzący zajęcia dydaktyczne podaje do wiadomości zakres materiału z danego przedmiotu oraz warunki jego zaliczenia. Studia podyplomowe kończą się uzyskaniem kwalifikacji podyplomowych. 
Dokonując szczegółowej analizy badań ankietowych oraz mając na uwadze konkluzje wynikające z przeprowadzonych wywiadów ze słuchaczami studiów podyplomowych „Rachunkowość budżetowa”, można sformułować następujące wnioski dotyczące prowadzenia dydaktyki zadaniowej oraz prawidłowej organizacji studiów podyplomowych:

1. Kluczową kwestią studiów podyplomowych jest poprawnie opracowany program studiów oraz odpowiednio dobrane przedmioty.

2. Należy przygotowywać materiały dydaktyczne na podstawie aktualnego stanu prawnego. Materiały te powinny być bardzo dobrze opracowane merytorycznie i przedstawione słuchaczom w przystępnej formie (np. konspekt i prezentacja multimedialna).

3. Przygotowując kolejne edycje studiów podyplomowych, zarówno w obszarze rachunkowości budżetowej, jak i studiów podyplomowych innych specjalności, szczególną uwagę powinno się zwrócić na zastosowane metody nauczania. Respondenci wyraźnie wskazali, iż nie są w pełni zadowoleni z metod prowadzenia zajęć. W przyszłości należy zaplanować mniej zajęć teoretycznych, a więcej ćwiczeń, case study, projektów, prac w grupach czy zajęć typowo warsztatowych.

4. Należy zwrócić szczególną uwagę, planując proces edukacji na studiach podyplomowych, na odpowiedni dobór kadry. Trzeba pamiętać, iż studia podyplomowe „Rachunkowość budżetowa" (podobnie jak inne studia podyplomowe są profilowane, ukierunkowane na określoną grupę słuchaczy) są kierowane do ludzi dorosłych, którzy pracują zawodowo. Nie można zatrudniać jedynie nauczycieli akademickich, gdyż głównym elementem tych studiów jest merytoryczna dyskusja na temat problemów praktyki gospodarczej. Słuchacze podkreślali, iż oczekują, aby wykładowcami byli:

- głównie wybitni praktycy,

- w równym stopniu pracownicy naukowo-dydaktyczni i praktycy.

5. Słuchacze podkreślali również, iż powinny być lepiej dostosowane godziny zjazdów do ich możliwości, co w praktyce będzie trudne do osiągnięcia ze względu na zatrudnienie poszczególnych uczestników studiów oraz ze względu na miejsce ich zamieszkania (często studia organizowane w Szczecinie czy Koninie skupiają uczestników z wielu różnych miejscowości).

6. Dydaktyka zadaniowa nie powinna być prowadzona w licznych grupach. Optymalna liczba słuchaczy w grupie, zapewniająca konstruktywną pracę warsztatową, to 15 osób.

7. Należy dołożyć wszelkich starań, aby zajęcia były prowadzone w lepiej wyposażonych salach dydaktycznych.

8. Zasady zaliczania poszczególnych przedmiotów (ćwiczeń oraz egzaminów) powinny być lepiej określone, przedstawione słuchaczom na początku semestru.

\section{PODSUMOWANIE}

Zgodzić się należy z Jankowską (2011), że podejście zadaniowe w dydaktyce, nazywane m.in. metodyką współpracy, uczeniem się przez działanie, uczeniem się przez doświadczenie, zakłada włączenie uczącego się do procesu dydaktycznego, a jego działania postrzegane są jako najlepszy sposób nabywania wiedzy i umiejętności. Nie chodzi już jedynie o odgrywanie ról i symulacje, lecz o kierowanie własnym uczeniem się, o przejęcie odpowiedzialności za 
działania dotyczące pozyskiwania wiedzy, o współkonstruowanie oraz wymianę wiedzy przy udziale innych uczących się, z których każdy wnosi do procesu swoje doświadczenia. Wzięcie pod uwagę osoby uczącej się w procesie dydaktycznym to uwzględnienie jej potrzeb w zakresie określania celów i treści nauczania, doboru środków dydaktycznych, a także specyficznych cech nauczania. Niezależnie od tego, jak rozumiemy i interpretujemy pojęcie „koncentracja na osobie uczącej się”, dydaktyka przywiązuje wielką wagę do potrzeb i celów uczącego się. W każdym procesie uczenia się słuchacz jest ważniejszy od tego, czego ma się nauczyć. Określanie potrzeb polega głównie na zdefiniowaniu tego, co stanowi istotę uczącego się: jego motywacji, otoczenia kulturowego, celów, do których dąży, oczekiwań, warunków, w których żyje, czasu, którym dysponuje, uwarunkowań instytucjonalnych.

Mając powyższe na względzie, podkreślić należy, iż organizacja studiów podyplomowych nie powinna mieć woluntarystycznego charakteru, dlatego istotną rolę w systemie organizowania dydaktyki zadaniowej studiów podyplomowych, w tym na kierunku rachunkowość budżetowa odgrywa zarówno kierownik studiów, jak i słuchacze poprzednich edycji.

\section{PIŚMIENNICTWO}

Autorski program kształcenia dla studiów podyplomowych „Rachunkowość budżetowa” obowiązujący w roku akademickim 2017/2018 zatwierdzony Uchwałą Rady Wydziału Zarządzania i Ekonomiki Usług nr 3.6/2/9/2016/2017. Szczecin, Uniw. Szczec. (materiały wewnętrzne).

Janowska I. 2011. Podejście zadaniowe do nauczania i uczenia się języków obcych. Red. W.T. Miodunko. Kraków, Universitas, 23-26.

Majchrzak I., Rydzewska-Włodarczyk M. 2013. Metody nauczania i ich wykorzystanie do kształtowania kompetencji społecznych pokolenia Y. Folia Pomer. Univ. Technol. Stetin. 72, 105.

Schultz T.W. 1981. The economics of being poor. Nobel prize lecture, in: Investing in people. Ed. T.W. Schultz. Berkeley, University of California Press, 3-17.

Stoker E., Streckeisen U., Wolter S.C. 1998. Indikatoren zum Humankapital. Neuchatel, Bundesamt für Statistik, 43.

Uchwała nr 155/2016 Senatu Uniwersytetu Szczecińskiego z dnia 24 listopada 2016 r. w sprawie uchwalenia Regulaminu studiów podyplomowych Uniwersytetu Szczecińskiego, http://www.usz.edu.pl, dostęp: 08.12.2017.

Wolter S.C. 2001. Bildungsfinanzierung zwischen Markt und Staat. 1. Zürich, Aufgabe, 16.

Streszczenie. Różnorodne są formy kształcenia oraz dostępność studiów, warsztatów, seminariów. Wiedzę, umiejętności oraz kompetencje dorośli mogą zdobywać i doskonalić między innymi na studiach podyplomowych. Celem niniejszego opracowania jest zaprezentowanie oceny kierunku studiów podyplomowych „Rachunkowość budżetowa” oraz próba odpowiedzi na pytanie: Jakich standardów nauczania oraz metodyki prowadzenia zajęć oczekują słuchacze studiów podyplomowych? Metodą badawczą była anonimowa ankieta przesłana słuchaczom, którzy byli uczestnikami studiów podyplomowych „Rachunkowość budżetowa", a narzędziem badań były opracowane kwestionariusze słuchaczy. 
